\title{
An ANALysis of EFL Autonomous LeARners in LEARNing ENGLiSH
}

\author{
(A Narrative Study) \\ ERICA FAJAR INDAH ${ }^{1}$, Dina RACHMAWATI ${ }^{2}$, SUTRIS SADJI \\ EVENDDY $^{3}$ \\ ${ }^{123}$ UNIVERSITAS SULTAN AGENG TIRTAYASA
}

\begin{abstract}
This research aimed to find out the factors affecting the autonomous learners in learning English and how these factors can influence the autonomous learners in learning English. This research employed qualitative narrative research. Narrative research was deemed to be relevant for this research since it deals with the specific phenomenon of the autonomous learner which analyzed life experience from the participants in learning English. The research subjects were two identified of autonomous learners. The data was taken by conducted interviews. In analyzing the data, the researcher used some procedures; data condensation, data display, and drawing conclusion/verification. The research revealed a finding related to the research question indicating that (1) internal and external factors were the factors affecting autonomous learners in learning English. From internal factors, it was argued that self-motivation (passion and willingness) was the biggest factor effecting autonomous learners eager to learn English. In addition, they also mentioned several external factors such as the family environment, school environment, and teachers as other factors that affected them in learning English (2) from several factors affecting autonomous learners in learning English, the participants also explained how these factors could encourage them in learning English, because of there were selfinitiation, self-direction, and self-realization in themselves that stimulate them to become autonomous in learning. From these findings, it can be inferred that teachers or lecturers could play a role to promote students learning autonomy in order to stimulate students' others positive psychological behavior, English proficiency and academic achievement.
\end{abstract}

Keyword: Autonomous learner, affecting factors 


\section{INTRODUCTION}

Autonomy in language learning has been a common topic that is often discussed among experts in learning English. The autonomous learner becomes one of the strategies used in teaching EFL (English as A Foreign Language) Teng (2019). Autonomous learning in language learning is known in various terms such as "learning independence", "self- direction", and "self-learning". All these terms are used to refer to similar concepts. Autonomous learners have particular characteristic in their learning such as they have their enthusiasm (Little D. , 2012) and responsibility in their learning (Liu, Wang, \& Ryan, 2016). Those traits identify that autonomous learner can produce good learning outcomes for themselves.

Furthermore, the important thing of autonomous learner is also highlighted by Palfreyman \& Smith (2004) that the autonomous learners decide what they want to learn or why they need to learn, and then decide how is going to handle the problems. It means an autonomous learner knows what they need and what they should do without any coercion from anyone. Therefore, teachers or lecturers who understands the effect of the autonomous learning will promote learners to become an autonomous learner.

In Indonesian context, the learning system has implemented the 2013 curriculum for elementary school, junior high school, and senior high school which student-centered learning methods in the teaching and learning process. This means that learning activities are student-centered and students are required to be more active. This proves that the education system in Indonesia has taught independence to students from elementary to high school so that they do not depend on a learning system that is only given by the teacher. Students must be able to explore as much knowledge as possible based on their will and independence.

However, preliminary research revealed that application of student-centered learning was not easy for lecturer, there were many obstacles that caused students to lack self-learning. In teaching activities, lecturer often found problems that occurred in students that must be handled. Several cases indicated that a common problem faced by EFL lecturers were dealing with passive classes, where students expected to be spoon-fed, did not participate in the class activities, and lack the initiative to learn. Most of them preferred to engage in the teaching learning activities when they were instructed directly by the lecturer. Consequently, the classseemed to be dominated by the lecturer.

In relation to the autonomous learners, many researches have discussed students autonomous learning were influenced by internal and external factors in learning English (Rahmah 2011, Katili 2013, Kemala 2016, Lestari 2019, Basri 2020). Those previous research used descriptive research inferred that internal factor (motivation) and external factors (social environment, assignments, 
teachers, and materials) had a positive impact on autonomous learners such as students becoming more independence in the learning they did, did not depending on knowledge only given by the teacher, know what they want to do, and have a purpose in learning to improve their ability and knowledge in English. Considering the discussion from those researches, it is implied that encouraging students to become autonomous learners in learning English will help students to develop their communicative English skills.

Therefore, the researcher is interested to investigate autonomous learning more deeply using narrative research with focus on autonomous learners since research concerning the factors that affect autonomous learners in learning English. The result of the research is expected to foster dependence learners to enhance their English skills.

\section{RESEARCH METHODOLOGY}

\section{a. Research Design}

This research employed a qualitative research method, and it used narrative inquiry. This research aims to obtain further information about the factors that affect the autonomous learners in learning English which will try to be described and analyzed. As explained by Creswell (2018) qualitative research is a type of research that explores and understands the meaning of a number of individuals or groups of people originating from social problems. In general, qualitative research is research conducted to find out about people's lives, beliefs, histories, behaviors, concepts or phenomena, social problems, and others.

The research design used by the researcher in this research was a narrative inquiry. Narrative inquiry is a research design that is used by the researchers to obtain data based on stories told by the narrator about their life experiences. As expressed by Barkhuizen, Benson, \& Chik (2014) that narrative inquiry is a research design that is used as a tool to collect stories and analyze the data found in the field.

\section{b. Source of Data}

In this research, the source of data is the factors that affect autonomous learners in learning English especially the English Department at one of the public Universities in Banten Province. The data will be taken from two students that have the characteristics of autonomous learner (Curiosity, intrinsically motivated, independence, critical thinking, discipline subject awareness, active in learning, are motivated to learn, are good guessers, and willing to take risks), has the highest average score in the structure-based writing subject and TOEFL scores 
above 550. In this research, the subject of this research was chosen to use a purposive sampling technique. According to Creswell (2018), the purposive sampling technique is a technique in which researcher select prospective subjects based on who can provide the desired information and share the information according to the criteria determined by the researchers themselves.

\section{c. Data Collection}

The data collection is taken by using narrative inquiry. Narrative inquiry is a research method that is used by the researcher to obtain data based on stories told by the narrator about their life experiences. As expressed by Barkhuizen, Benson, \& Chik (2014) that narrative inquiry is a research design that is used as a tool to collect stories and analyze the data found in the field. In line with the statement above, this research wants to find out and analyze the learning experiences carried out by autonomous learners in learning a language, so that narrative inquiry was the suitable research design that the researcher could use to collect the data.

\section{DISCUSSION}

\section{Factors Affecting Autonomous Learners in Learning English}

Data analysis revealed that internal and external factors are the contributing factors on autonomous learners in learning English. Further detailed analysis indicated that motivation (internal factor), and family and school environment (external factor), are three contributing factors on autonomous learners in learning English. More elaborations are provided in the following sections.

\section{A. Internal Factors}

Students' internal factors in language learning cover aspects of age, gender, motivation, intelligence, and personality Mahmoudi \& Mahmoudi (2015). The finding in this research shows that motivation is the only internal factor that affects autonomous learners in learning English. All the participants have the same internal factor, namely motivation. The results of this research same as the previous research conducted by Kemala (2016) with the title factors influencing autonomous learners in learning English whose research results show that motivation was an internal factor that affects autonomous learners in learning English. For further discussion will be discussed below: 


\section{a. Motivation}

Related to this research, all the autonomous learners in this research participants were affected by motivation in learning English. The autonomous learners in this research are influenced by their passion and willingness as their motivation. Motivation is defined as the strength or power that is possessed by a learner to create passion, joy, and willingness to do or learn something new and provide optimism to face failure Gelperin (2017). One of the motivational orientations was related to be independence. The autonomous learners think when learning something based on our desire and there is no coercion from anyone, it will bejoyful.

For example:

\section{- Passion}

The results of this research indicate that $\mathrm{S} 1$ has one utterance which indicates that passion is S1's motivation in learning. Meanwhile, S2 has two utterances that show S2's motivation in learning is passion. This finding is in line with the research conducted by Kemala (2016) entitled "factors influencing autonomous learners in learning English" in which the research results show that passion was their motivation in learning. Passion-based learning uses students' passion to help them to learn something. Passion-based learning uses their strengths to teach their weaknesses Gelperin (2017). For example, someone is difficult to memorize but likes to listen the songs, so listening to a song can be used as an alternative in memorizing. Here is an autonomous learner's passion for learning English.

S2:

"Because the Disney channel is fun, I like the artist and because I like the artist. I feel compelled to understand the meaning of the conversation thev are having. so there is no pressure from anvwhere, but I am encouraged and feel need to understand the story of the channel. Because I think if you just watch it, you don't know the storyline and it's not fun for sure."

"I was motivated to learn English for the first time when I was eleven years old, because I S1:

idolized a foreign artist, Justin Bieber. At that time. Idid not understand English, but 
everv time I listened to his songs, I wanted to understand everv word that was said by Lustin Bieber so I gradually learned English through the implied lyrics of his songs."

S2: "I was motivated to learn English for the first time when I was eight years old. At that time, I really enjoyed watching the Disney channel, I was happy with the artists. Almost everv time I got a chance, I always watched the Disnev channel. At that time, I did not understand English. but I was motivated to learn English because I often watched the channel. This is where I was first motivated to learn English because I wanted to understand the meaning of the conversations being held on the channel."

The underlined sentences above illustrate the students' passion to learn English. The findings showed the participants had a strong enthusiasm and excitement on the participants in learning English. The statement above proved from what was state by Liston \& Garrison (2004) that passion for learning is a strong feeling of enthusiasm or excitement for something or about doing something.

\section{- Willingness}

The results of this research indicate that $\mathrm{S} 1$ has two utterances which indicate that willingness is S1's motivation in learning. Meanwhile, S2 has three utterances that indicate that willingness is S2's motivation in learning. The finding of this research is the same as the research results conducted by Basri (2020) entitled "Analyze factors influencing autonomous learners and autonomy support in a faculty of education, Teaching in Higher Education" stated that willingness is an internal factor that affects student learning. Willingness to learn is defined as a desire, wish, or readiness to acquire new knowledge and develop ability Gelperin (2017). It means that a person does not want to stand in one place, wishes to be more qualified, and keep up with the modern trends and tendencies. Here is an autonomous learner's willingness in learning English.

\section{S2:}

"The school environment and teachers at that time did not really affect me, Idid all the $\underline{\text { learning }}$ activities based on mv interest and will." 
S1:

"Starting as a hobby, I continued to like English, then when I watched movies or listened to music, I was indirectly curious about new vocabulary and a lot of new vocabulary that I didn't know before, so I understood. At the same time. I immediatelv searched for the meaning of the vocabularv. Then, at that moment I thought that English has become a foreign language that must be mastered nowadays, because in the future this language will be very useful, so if I don't understand it, it will be outdated."

"So, when watched a movie or listened to a song there are some words that I didn't know the S2: meaning of, at the same time I immediatelv find out the meaning of the words, and when I already know the meaning of the vocabulary, I usually like to use these words in the conversations I have. So indirectly I'm learning without knowing I'm learning. "

"When I was in school, the role of the teacher did not reallv affect me in learning English. I am motivated a lot by myself."

S2: "At that time when I was about eleven years old learning English was a necessitv because when I was in elementary school, English lessons were already there and when the final school exams were in English, plus when I was in junior high school, the National Examination had English lessons. That's why I think English needs to be learned."

S1: The underlined sentences above illustrate the students' willingness to learn English. The

findings showed that they have a desire to acquire knowledge and develop skills to improve their learning achievement in their own way. The statement above is related to Stipek (2004) states that willingness to learn is defined as a desire, wish, or readiness to acquire new knowledge and develop skills.

\section{B. External Factors}

Besides internal factors that affect the autonomous learners in learning English, other factors that affect autonomous learner in learning English are external factors. Students' external factors in language learning cover family, parents, school, teacher, and the surrounding environment Mahmoudi \& Mahmoudi (2015). This research data analysis found 
that the external factors that affect learner autonomy in learning English are family, school environment, and teacher.

This research indicates that $\mathrm{S} 1$ and $\mathrm{S} 2$ each show an utterance that the external factor that affects the participants in learning English is family. The next external factor that affects autonomous learners in learning English is a school only from S1 and the next external factor that affects autonomous learners is the teacher also only in S1. The results of this research same as the previous research conducted by Lestari (2019) with the title "Factors Influencing Learner Autonomy in Learning English at The Eleventh Grade of Ma Darul Hikmah Tawangsari Tulungagung" who said that the external factors that affect the autonomous learner are family, school environment, and teacher.

\section{Environment}

The result showed that all the autonomous learners were also affected by environmental factors in learning English. The environment is an influential factor in a student's learning system. Lewin (2000) revealed that a supportive school and family environment will form good study habits for a student. In this research, all the autonomous learners learning English were affected by their family and school environment. Further explanations are as follows:

\section{a. Family}

Family is one of the important factors that can affect the independence of students in gaining knowledge. A supportive family environment will foster students' enthusiasm for learning which will have a good impact on their learning outcomes Lewin (2000). The following are the answers given by the informants regarding the factors that can affect the participants in learning English is family.

S1:

"My father used to always plav English songs, so indirectly I became enthusiastic about English because of mv father and little by little I learned English vocabulary from songs that my father often played."

S2: "Even though no one in mv familv can speak English, but thev alwavs support me to continue learning English, so at that time I often practiced my English skills by speaking 
English only with myself, often reading novels and writing stories. My family knows my habit like this and always supports me."

The underlined sentences above illustrate the students' interest to learn English because of their family support. The findings showed that the family has an important role in supporting autonomous learners to learn English. It proved what was stated by Lewin (2000) that a supportive family environment will foster students' enthusiasm for learning which will have a good impact on their learning outcomes

\section{b. School}

Besides family, the school environment is a supporting factor that affects students in learning English. A school is a place for teaching and learning, and a place for students to get lessons Stipek (2004), therefore a pleasant school environment will help students be enthusiastic in gathering knowledge. The following are the answers given by participants regarding the school environment that affects autonomous learners in learning.

S1:

"Besides that, when I entered Senior High School, mv school used three languages, one of which was English. like it or not, I had to be able to speak English because my daily conversation was in English."

The underlined sentence above illustrates the students' responsibility to learn English. The findings showed that the autonomous learners have the responsibility to be able to speak English because of the demands and encouragement given by the school which requires every student to use English when they want to communicate. In line with this finding Stipek (2004) stated that a supportive school environment for the teaching and learning process will help students to be enthusiastic in gathering knowledge.

\section{c. Teacher}

The success of students to be active and enthusiastic when learning depends on the ability of the teacher to make students interested in learning. Teachers must be able to provide comfortable teaching and learning situations for students, so that they can influence students' own motivation to learn Teng (2007). In line with the statement above, this research found that the teacher is one of the factors can influence autonomous learner in learning English. 
S1:

"One of the factors is the teacher, I feel motivated to learn English because of my English teacher."

The underlined sentence above illustrates the students' motivation to learn English. The findings showed that the autonomous learner was interested in learning English influenced by the role of the teacher who was interesting and knowledgeable. It is related to what was stated in previous research that interesting and good activities from the teacher will motivate students to learn more Morris (2006).

\section{How The Factors Influence Autonomous Learners in Learning English}

This research question refers to how the internal and external factors of the students influence autonomous learning. The data analysis revealed that motivation, family, and school environment factors influence autonomous learning participants through the participants' ability to set goals, plan, and evaluate their learning. In other words, the participants know what they need to do and what they need to improve from their language skills and competence.

In this research, the concept of self-determination of Shogren \& Raley (2018) was adapted to discusses how the internal and external factors generate learners' learning autonomy. The findings show that the internal and external factors can influence the autonomous in learning English because of there are self-initiation, self-direction, and self-realization in themselves that encourages them to be autonomy in learning system they did.

\section{CONCLUSION AND SUGGESTION}

\section{- Conclusion}

This research found two findings, first there are two factors that affect autonomous learners in learning English, specifically internal factor (motivation) external factors (family, school, and teacher) that affected the autonomous learners in learning autonomy. These factors can be influenced by their motivation such as passion and willingness, and social aspect such as family environment, school environment and teacher which improve their knowledge, vocabulary and ability in English. Second, for the research question about how these factors can influence autonomous learners in learning English there were self-initiation, self- direction, and self-realization that influence them to be autonomous. 
Those findings imply that knowing the factors affecting the autonomous learners in learning English helps to promote the students to become autonomous learners in the classroom that might improve their positive psychological behavior, English proficiency andacademic achievement.

\section{- $\quad$ Suggestion}

Finally, the researcher would like to give some suggestions for students, teachers, and further researchers.

1. For students out there, the researcher hopes that positive factors that can affect students to become autonomous learners can motivate other students to be interested in learning English.

2. For English teachers or lecturers, the researcher suggests that teachers or lecturers be more creative in using media, and make interesting materials in teaching English. With the creativity of the teacher and lecturer, and the presentation of interesting material provided by the teacher or lectures to students, it can be a motivation for students to learn English.

And lastly, for the next researcher who wants to conduct narrative research, the interview process is better done directly to see the body gestures of the informant.

\section{REFERENCES}

Barkhuizen, G., Benson, P., \& Chik, A. (2014). Narrative Inquiry In Language Teachingin Language Teaching. Routledge.

Basri, F. (2020). analyzes factors influencing learner autonomy and autonomy support in a faculty of education, Teaching in Higher Education. Tandfonline.

Creswell, J. W., \& Creswell, J. (2018). Research Design: Qualitative, Quantitative, and Mixed Methods Approaches. SAGE Publications, 1-5063-8671-7.

Gelperin, R. (2017). Addiction, Procrastination, and Laziness: A Proactive Guide to the Psychology of Motivation. Self-Help, Relationships \& Lifestyle - The Art of Communication.

Kemala, Z. (2016). An Analysis of Factors Influencing The Autonomous Learners in Learning English. ELTIN Journal, Volume 4/I.

Lestari, W. (2019). Factors Influencing Learner Autonomy in Learning English at The Eleventh Grade Of Ma Darul Hikmah Tawangsari Tulungagung. English Education Department Faculty of Tarbiyah and Teacher Training State Islamic Institue of Tulung Agung. 
Lewin, K. (2000). Principles of topological psychology. New York: McGraw.

Liston, D., \& Garrison, J. (2004). Teaching, Learning, and Loving, Reclaiming Passion in Educational. Routledgefalmer.

Little, D. (2012). The Common European Framework of Reference for Languages and the European Language Portfolio: Some history, a view oflanguage learner autonomy, and someimplications for language learning in higher education. Centre for Language and Communication Studies, Trinity College, Dublin, Ireland.

Liu, W. C., Wang, J., \& Ryan , R. (2016). Building Autonomous Learners: Perspectives from Research and Practice using Self-Determination Theory. Springer Singapore.

Mahmoudi, S., \& Mahmoudi, A. (2015). Internal and External Factors Affecting Learning English as a Foreign Language . International Journal of Language and Linguistics, 313-322.

Morris, W. (2006). Creativity Its Place In Education. New Zealand.

Palfreyman, D., \& Smith, R. (2004). Learner Autonomy Across Cultures: Language Education Perspectives. Linguistics.

Shogren, \& Raley. (2018). The Self-Determined Learning Model of Instruction. Kansas University Center.

Stipek, D. J. (2004). Engaging School (Fostering High School Students' Motivation to learn). National Research Council.

Teng, F. (2007). Autonomy, Agency, and Identity in Teaching and Learning English as a Foreign Language. Springer Singapore.

Teng, F. (2019). Autonomy, Agency, and Identity in Teaching and Learning English as a Foreign Language. Springer Singapore. 